\title{
Experimental design for the optimization of propidium monoazide treatment to quantify viable and non-viable bacteria in piggery effluents
}

\author{
Jérémy Desneux ${ }^{1,2}$, Marianne Chemaly ${ }^{2,3}$ and Anne-Marie Pourcher ${ }^{1,2^{*}}$
}

\begin{abstract}
Background: Distinguishing between viable and dead bacteria in animal and urban effluents is a major challenge. Among existing methods, propidium monoazide (PMA)-qPCR is a promising way to quantify viable cells. However, its efficiency depends on the composition of the effluent, particularly on total suspended solids (TSS)) and on methodological parameters. The aim of this study was evaluate the influence of three methodological factors (concentration of PMA, incubation time and photoactivation time) on the efficiency of PMA-qPCR to quantify viable and dead cells of Listeria monocytogenes used as a microorganism model, in two piggery effluents (manure and lagoon effluent containing 20 and 0.4 TSS g. $\mathrm{kg}^{-1}$, respectively). An experimental design strategy (Doehlert design and desirability function) was used to identify the experimental conditions to achieve optimal PMA-qPCR results.
\end{abstract}

Results: The quantification of viable cells of L. monocytogenes was mainly influenced by the concentration of PMA in the manure and by the duration of photoactivation in the lagoon effluent. Optimal values differed with the matrix: $55 \mu \mathrm{M}$ PMA, 5 min incubation and 56 min photoactivation for manure and $20 \mu \mathrm{M}$ PMA, 20 min incubation and 30 min photoactivation for lagoon effluent. Applied to five manure and four lagoon samples, these conditions resulted in satisfactory quantification of viable and dead cells.

Conclusion: PMA-qPCR can be used on undiluted turbid effluent with high levels of TSS, provided preliminary tests are performed to identify the optimal conditions.

\section{Background}

Accurate and reliable detection of viable pathogenic bacteria in complex matrices like manure and biosolids is a major challenge. Few molecular methods have been developed to differentiate viable from dead cells. Reverse transcription-PCR (RT-PCR) has been used to study the behavior of viable pathogenic bacteria in manured soil $[1,2]$ and in sludge [3]. However, its use is limited by the difficulty in extracting high quality RNA, by the instability of RNA, and by variations caused by the physiological condition of the cells [4]. The Live/Dead BacLight viability assay can detect viable bacteria but this microscopic method is not suitable for environmental matrices due to

\footnotetext{
* Correspondence: anne-marie.pourcher@irstea.fr

'IRSTEA, 17 avenue de Cucillé, 35044 Rennes, France

${ }^{2}$ Université Européenne de Bretagne, Rennes, France

Full list of author information is available at the end of the article
}

interactions between the dye and organic matter [5]. Ethidium monoazide (EMA) or propidium monoazide (PMA) coupled with real-time quantitative PCR (qPCR) have been used to distinguish viable from dead bacteria $[6,7]$. These DNA intercalating dyes selectively enter cells with compromised membrane and bind covalently to DNA after photoactivation, thus preventing subsequent PCR amplification [8, 9]. Comparative studies showed that PMA outperformed EMA in the selective removal of dead cells $[8,10,11]$. Despite its advantages over EMA, there is evidence that PMA has limitations when applied to complex environmental matrices [9, 12, 13]. High levels of total suspended solids (TSS) or biomass in sludge or in water samples appeared to interfere with the ability of the PMA-qPCR method to quantify viable bacteria [14]. Indeed, the high organic matter content in sludge and manures and the high turbidity of these matrices may 
interfere with the photoactivation process. In addition, organic matter provides chemically active cation exchange sites that may retain the PMA and consequently reduce the available concentration of dye [15]. Questions therefore still remain about the applicability of PMA in such matrices.

Several methodological parameters may affect PMA efficiency. Among them, the concentration of the dye, the length of light exposure and of incubation appear to be key parameters [12] that require optimization for the reliable quantification of dead microorganisms. Studies on the use of PMA to quantify non-viable bacteria in effluents are rare and are all based on the works of Nocker et al. [9, 16, 17] and Luo et al. [18]. In these studies, the samples were exposed to a $600-650-\mathrm{W}$ halogen light source placed at a distance of $20 \mathrm{~cm}$ from the tubes and light exposure time ranged from 1 to 20 min depending on the experiment [19-21]. The incubation time in the dark also varied, ranging from five $[9,14,19,20]$ to $10 \mathrm{~min}[22]$, while PMA concentrations ranged from $2 \mu \mathrm{M}$ [19] to $300 \mu \mathrm{M}$ [14]. Due to the lack of data on livestock and urban effluents, the optimal conditions of the PMA application are still not clear and require further investigation.

As a model for the present study, we used Listeria monocytogenes, a pathogen that has been reported to enter a viable but nonculturable (VBNC) state $[23,24]$ and whose presence has been reported in both urban and animal effluents [5, 25]. We determined the optimal conditions of the PMA-qPCR method in two types of piggery effluents that differed in their chemical and physical properties: raw manure and biologically treated liquid manure (lagoon effluent). To this end, we compared the quantification of living (viable) and heat-killed (dead) cultured L. monocytogenes cells using PMA-qPCR, qPCR and a cultural method. To simultaneously study the effect of (i) the concentration of PMA, the length of light exposure and of incubation in the dark and (ii) the interaction of these three factors, a response surface method based on a Doehlert design and a desirability function were applied to identify the optimal conditions for the quantification of VBNC cells of L. monocytogenes. To check the applicability of the method, the optimal conditions we identified were tested on nine piggery effluents.

\section{Results}

Use of the desirability approach to determine the optimal conditions for PMA pretreatment

We studied the concentration of PMA, incubation time and photoactivation time in a raw manure and in a lagoon effluent using an experimental design matrix based on a Doehlert design (Table 1). The lowest $\Delta_{\text {dead }}$ values were 1.2 in the lagoon effluent and $2.4 \log _{10}$ cfu-eq in the manure. It is noteworthy that the maximum theoretical $\Delta_{\text {dead }}$ value (4.1 in manure and 3.4 in lagoon) depended on the concentration of inoculated cells and

Table 1 Design matrix of the Doehlert uniform shell design for 3 factors and corresponding responses

\begin{tabular}{|c|c|c|c|c|c|c|c|}
\hline \multirow[t]{3}{*}{ Run } & \multicolumn{3}{|l|}{ Factors } & \multicolumn{4}{|c|}{ Responses ( $\log _{10}$ cfu-eq) } \\
\hline & \multirow[t]{2}{*}{ PMA concentration $(\mu \mathrm{M})$} & \multirow[t]{2}{*}{ Incubation time (min.) } & \multirow[t]{2}{*}{ Photoactivation time (min.) } & \multicolumn{2}{|c|}{ Manure } & \multicolumn{2}{|c|}{ Lagoon } \\
\hline & & & & $\overline{\Delta_{\text {viable }}}$ & $\Delta_{\text {dead }}^{\mathrm{b}}$ & $\Delta_{\text {viable }}$ & $\Delta_{\text {dead }}$ \\
\hline $1^{a}$ & 160 & 17.5 & 29 & 1.2 & 3.4 & 1.0 & 3.4 \\
\hline 2 & 160 & 17.5 & 29 & 0.9 & 3.4 & 1.0 & 3.4 \\
\hline 3 & 160 & 17.5 & 29 & 1.1 & 3.4 & 1.0 & 3.4 \\
\hline 4 & 160 & 17.5 & 29 & 1.1 & 3.4 & 1.0 & 3.4 \\
\hline 5 & 300 & 17.5 & 29 & 1.6 & 4.1 & 1.2 & 3.4 \\
\hline 6 & 20 & 17.5 & 29 & 0.2 & 2.7 & 0.1 & 3.4 \\
\hline 7 & 230 & 17.5 & 56 & 1.3 & 4.1 & 1.2 & 3.4 \\
\hline 8 & 90 & 17.5 & 2 & 0.6 & 2.4 & 0.4 & 2.5 \\
\hline 9 & 230 & 17.5 & 2 & 1.2 & 2.4 & 0.3 & 2.5 \\
\hline 10 & 90 & 17.5 & 56 & 0.6 & 3.1 & 1.0 & 3.4 \\
\hline 11 & 230 & 30 & 38 & 1.0 & 4.1 & 0.6 & 3.4 \\
\hline 12 & 90 & 5 & 20 & 0.6 & 2.9 & 0.3 & 1.2 \\
\hline 13 & 230 & 5 & 20 & 1.2 & 3.3 & 0.7 & 3.4 \\
\hline 14 & 160 & 5 & 47 & 0.8 & 4.1 & 0.8 & 3.4 \\
\hline 15 & 90 & 30 & 20 & 0.5 & 3.2 & 0.7 & 3.4 \\
\hline 16 & 160 & 30 & 11 & 1.0 & 4.1 & 0.6 & 3.4 \\
\hline
\end{tabular}

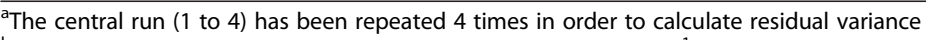

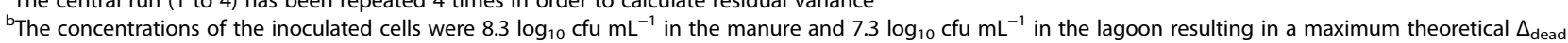
value of 4.1 and 3.4 , respectively 
on the limit of quantification of the qPCR. This maximum value was reached for 5 and 10 combinations of factors in manure and lagoon effluent, respectively. The values of $\Delta_{\text {viable }}$ ranged from 0.2 to $1.3 \log _{10}$ cfu-eq in manure and from 0.1 to $1.0 \log _{10}$ cfu-eq in lagoon effluent, demonstrating that the combination of the three methodological factors affected the efficiency of the PMA-qPCR.

The minimum value of $\Delta_{\text {viable }}$ was observed for a PMA concentration of $20 \mu \mathrm{M}$, an incubation time of $17.5 \mathrm{~min}$ and a photoactivation time of $29 \mathrm{~min}$ in both matrices. Under these conditions, the $\Delta_{\text {dead }}$ value reached the limit of quantification in the lagoon but was $2.7 \log _{10}$ cfu-eq in the manure, indicating an underestimation of 1.4 $\log _{10}$ cfu-eq of the dead cells in this matrix.

The estimated effects of the three independent factors with their second-order interactions on the $\Delta_{\text {viable }}$ and $\Delta_{\text {dead }}$ responses are presented on the standardized Pareto charts in Fig. 1, which graphically displays the magnitude of the effects according to the statistical analysis of the experimental data. The effects are ranked in descending order. Analysis of the data showed that the significance of the variables depends on the nature of the matrix. When viable L. monocytogenes was inoculated in manure, the PMA concentration were the most important factor affecting the $\Delta_{\text {viable }}$ values (Fig. 1a). The two other factors had little or no significant effect on the $\Delta_{\text {viable }}$ values. On the other hand, when viable bacteria were inoculated in the lagoon, only the length of the photoactivation period had a positive effect on the $\Delta_{\text {viable }}$ values (Fig. 1b). The interpretation of the significance of the factors obtained with the dead cells was more difficult given the high number of similar responses corresponding to runs in which the limit of quantification of the qPCR was reached. This may explain the low significance of the three factors observed in the lagoon effluent (Fig. 1d) and the high number of factors and interactions influencing the $\Delta_{\text {dead }}$ values in manure (Fig. 1c). Nevertheless, overall, the reduction in $\Delta_{\text {viable }}$ and the increase in $\Delta_{\text {dead }}$ values were mainly affected by the concentration of PMA and /or the length of the photoactivation period, whereas incubation time had less impact.

According to the results of the Doehlert design, it is clear that (i) the type of matrix played a role in the effect of the factors and (ii) the $\Delta_{\text {viable }}$ and $\Delta_{\text {dead }}$ responses

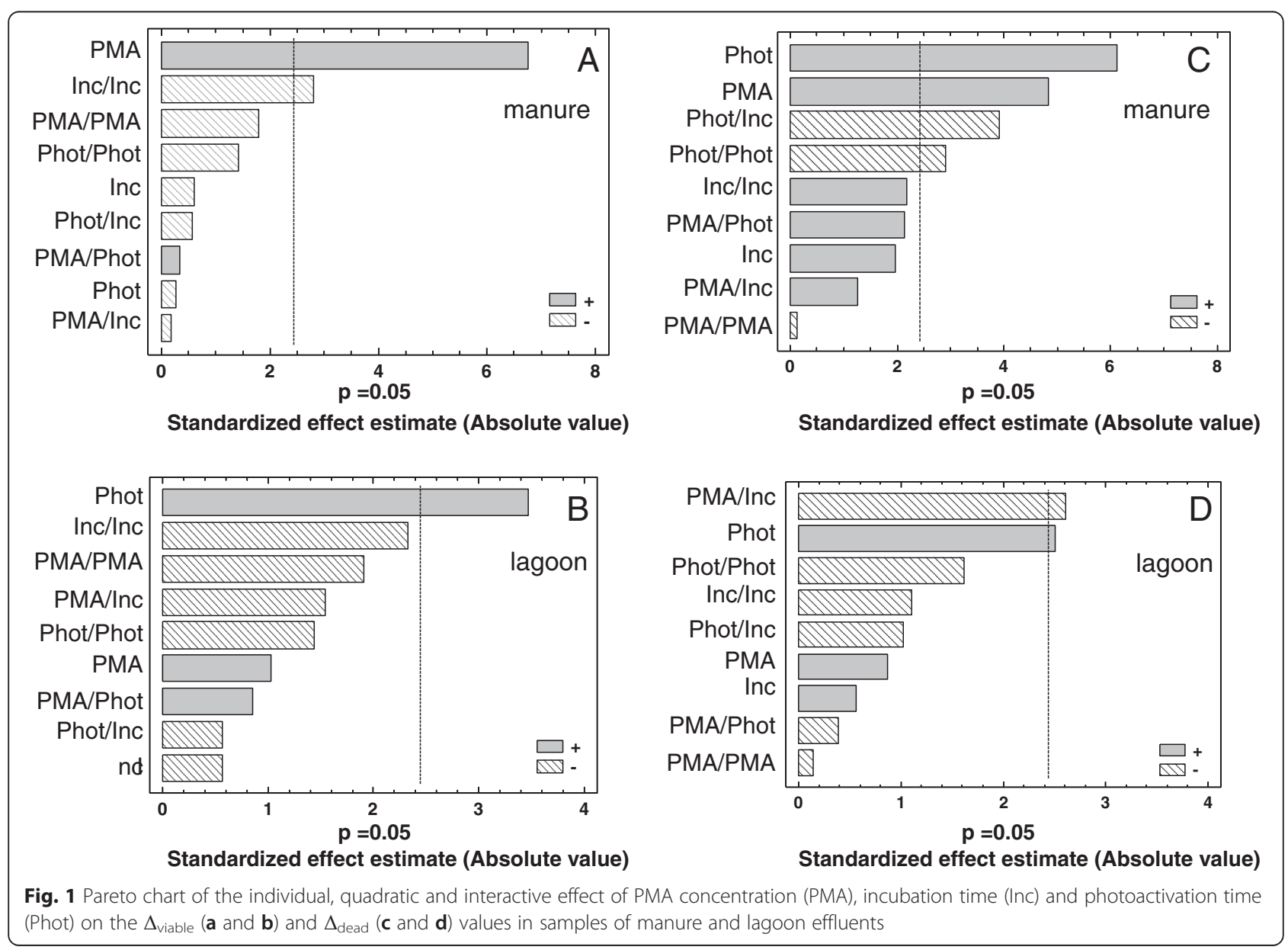


were contradictory. In order to find the best compromise between the two responses, a composite desirability function was calculated by simultaneous minimization of the $\Delta_{\text {viable }}$ response and maximization of the $\Delta_{\text {dead }}$ response. Statgraphics Centurion XVI software was used to calculate the optimal conditions. The results of the predicted values of the desirability function for each run of the Doehlert design are listed in Table 2. The three factors needed to maximize desirability for the manure (run 14) differed from those needed for the lagoon effluent (run 6). The optimal conditions to achieve the highest value of the overall desirability function were $55 \mu \mathrm{M}$ PMA, 5 min incubation and 56 min photoactivation for manure and $20 \mu \mathrm{M}$ PMA, 20 min incubation and $30 \mathrm{~min}$ photoactivation for lagoon effluent, all of which were computed by Statgraphics Centurion XVI software.

\section{Applying the optimal conditions to manures and lagoon effluents}

The optimal conditions determined by the desirability function were applied to five manures and four lagoon effluents inoculated with viable and heat-killed $L$. monocytogenes cells to estimate the effect of the matrices on the $\Delta_{\text {viable }}$ and the $\Delta_{\text {dead }}$ responses with the same PMA pretreatment. The physico-chemical characteristics and responses are listed in Table 3 . The $\Delta_{\text {viable }}$ responses ranged from 0.12 to $0.83 \log _{10}$. Regardless of the matrix, seven of the nine $\Delta_{\text {viable }}$ responses resulted in slight underestimation of the viable $L$. monocytogenes cells (less than $0.5 \log _{10} \mathrm{cfu}$-eq). In seven of the nine samples, the observed $\Delta_{\text {dead }}$ were close to the theoretical

Table 2 Predicted values of the desirability function at each point conditions set for manure and lagoon

\begin{tabular}{lll}
\hline Run & Predicted value & \\
\cline { 2 - 3 } & Lagoon & Manure \\
\hline 1 to 4 & 0.426 & 0.464 \\
5 & 0.454 & 0.173 \\
6 & $0.819^{\mathrm{a}}$ & 0.411 \\
7 & 0.000 & 0.498 \\
8 & 0.609 & 0.000 \\
9 & 0.659 & 0.174 \\
10 & 0.605 & 0.508 \\
11 & 0.602 & 0.600 \\
12 & 0.456 & 0.475 \\
13 & 0.596 & 0.364 \\
14 & 0.494 & $0.705^{\mathrm{a}}$ \\
15 & 0.721 & 0.678 \\
16 & 0.754 & 0.652 \\
\hline
\end{tabular}

${ }^{a}$ The numbers in bold indicate the run corresponding to the higher overall desirability maximum value of $\Delta_{\text {dead }}$ (3.2 and $3.5 \log _{10}$ cfu-eq for manures and lagoons, respectively), suggesting the underestimation of heat-killed cells was very small. Two manure samples (M3 and M4) had a lower $\Delta_{\text {dead }}$ value than those of the other samples, resulting in a 0.7 and $0.8 \log _{10}$ underestimation of dead cells, respectively. As, except for samples M3 and M4, the $\Delta_{\text {dead }}$ responses were close to the limit of quantification, only the relationships among $\Delta_{\text {viable }}$ responses and physico-chemical parameters were analyzed. The turbidity of the lagoons was positively correlated with $\Delta_{\text {viable }}$ (Spearman's $\rho=1.0 ; p<0.0001$ ) whereas none of the factors were correlated with $\Delta_{\text {viable }}$ in manure, confirming that turbidity played a major role in the less turbid matrix.

\section{Discussion}

The DNA-intercalating agent PMA was used in combination with qPCR for the detection of the viability of bacterial cells. This rapid method does not require cell culture and is consequently particularly attractive for the detection of pathogenic bacteria that can enter a viable but nonculturable (VBNC) state such as L. monocytogenes [23, 26]. PMA has been used on a wide range of microorganisms (vegetative and spore forming bacteria, fungal cells, viruses, protozoa) and successfully tested on simple matrices such as broth culture or water samples [19, 27-34]. However, the complex nature of environmental matrices (e.g. urban effluent, sludge, manure) has been shown to influence the effectiveness of the PMA-qPCR $[14,15,19,20,35,36]$. Factors such as turbidity and the concentration of solids [4, $15,16,18-21], \mathrm{pH}$ [37], and of organic matter [35, 38] may reduce the efficiency of dye pretreatment. Indeed, the presence of solids and organic matter in urban effluents and sludge interferes with the penetration of PMA into microorganisms with compromised cell membrane integrity $[14,19-22]$, resulting in underestimation of the number of dead cells. One suggested way of overcoming this bias is diluting the environmental matrices. However, this reduces the concentration of the target organism and, as a result, reduces the sensitivity of the method.

Although the efficiency of PMA-qPCR, PMA may also be affected by methodological factors such as the concentration of PMA, the length of photoactivation and incubation $[9,14,19,20]$, the combination of the three factors tested on effluents and sludge in published literature were mostly similar (i.e. PMA $100 \mu \mathrm{M}$, incubation time $5 \mathrm{~min}$ and photoactivation time 2 to $5 \mathrm{~min}$ ).

The results of our experiments performed on raw pig manure, a brown matrix containing $20 \mathrm{~g} \mathrm{~L}-1$ TSS and lagoon effluent, which was less colored and contained about 50 times less TSS, revealed that the efficiency of the PMA treatment is influenced by the type of effluent and thus require optimization of the methodological factors. The optimal combination of the three factors 
Table 3 Physico-chemical parameters and $\Delta_{\text {viable }}$ and $\Delta_{\text {dead }}$ responses (expressed in $\log _{10}$ cfu-eq) after PMA pretreatment of 5 manures and 4 lagoon effluents

\begin{tabular}{|c|c|c|c|c|c|c|c|}
\hline Matrix & Sample & $\Delta_{\text {viable }}$ mean $\pm S D^{b}$ & $\Delta_{\text {dead }}^{\mathrm{a}}$ mean $\pm \mathrm{SD}$ & $\mathrm{pH}$ & Turbidity (NTU) & VS $\left(\mathrm{g} \cdot \mathrm{kg}^{-1}\right)$ & TSS $\left(\mathrm{g} \cdot \mathrm{kg}^{-1}\right)$ \\
\hline \multirow[t]{6}{*}{ manure } & M1 & $0.15 \pm 0.2^{C}$ & $2.97 \pm 0.3^{\mathrm{A}}$ & 7.6 & 2612 & 6.3 & 3.8 \\
\hline & $\mathrm{M} 2$ & $0.83 \pm 0.1^{\mathrm{A}}$ & $3.25 \pm 0.0^{\mathrm{A}}$ & 8.2 & 2660 & 7.6 & 5.9 \\
\hline & M3 & $0.49 \pm 0.2^{\mathrm{ABC}}$ & $2.51 \pm 0.3^{B}$ & 7.3 & 4624 & 22.8 & 14.8 \\
\hline & M4 & $0.29 \pm 0.3^{B C}$ & $2.40 \pm 0.2^{B}$ & 7.5 & 3323 & 19.8 & 12.9 \\
\hline & M5 & $0.21 \pm 0.1^{c}$ & $2.93 \pm 0.2^{A}$ & 7.6 & 3580 & 12.4 & 10.5 \\
\hline & Mean & $0.39 \pm 0.3$ & $2.81 \pm 0.4$ & $7.7 \pm 0.3$ & $3360 \pm 821$ & $13.8 \pm 7.3$ & $9.6 \pm 4.7$ \\
\hline \multirow[t]{5}{*}{ Lagoon } & L6 & $0.12 \pm 0.1^{c}$ & $3.35 \pm 0.0^{\mathrm{A}}$ & 8.5 & 102 & 1.6 & 0.9 \\
\hline & L7 & $0.36 \pm 0.1^{\mathrm{BC}}$ & $3.35 \pm 0.0^{A}$ & 8.4 & 120 & 1.2 & 0.55 \\
\hline & L8 & $0.46 \pm 0.1^{B C}$ & $3.35 \pm 0.0^{\mathrm{A}}$ & 8.4 & 461 & 1.8 & 1.1 \\
\hline & L9 & $0.69 \pm 0.1^{\mathrm{ABC}}$ & $3.12 \pm 0.3^{A}$ & 8.4 & 772 & 1.3 & 1.0 \\
\hline & Mean & $0.41 \pm 0.2$ & $3.29 \pm 0.2$ & $8.4 \pm 0.0$ & $364 \pm 318$ & $1.5 \pm 0.3$ & $0.9 \pm 0.2$ \\
\hline
\end{tabular}

The values followed by different capital letters are statistically different according to a Student-Newman-Keuls test

aThe concentrations of the inoculated cells were $7.4 \log _{10} \mathrm{cfu} \mathrm{mL} \mathrm{mL}^{-1}$ in the manure and $7.5 \log _{10} \mathrm{cfu} \mathrm{mL} \mathrm{m}^{-1}$ in the lagoon, resulting in a maximum theoretical $\Delta_{\text {dead }}$ value of 3.2 and 3.5 , respectively

${ }^{\mathrm{b}}$ mean of triplicates \pm standard deviation

obtained with the desirability function clearly differed between the manure and the lagoon samples. The analysis of the data of the Doehlert design identified the concentration of PMA in the manure and the photoactivation time in the lagoon effluent as the factors that most influenced $\Delta_{\text {viable }}$ responses, whereas incubation time was less significant. These results suggest that in turbid matrices such as manure or sludge, the photoactivation time plays a minor role compared to the concentration of PMA and vice versa in less turbid matrices.

The significance and the interaction of factors affecting the $\Delta_{\text {dead }}$ responses were less clear due to the high limit of quantification of the qPCR, which was reached in 76 and $38 \%$ of the experimental runs in lagoon effluent and in manure, respectively (Table 1). Experiments performed in broth or water with a pure culture of dead cells resulted in a reduction of the cell quantification of between 3 and $5 \log _{10}$ after PMA or EMA pretreatment $[14,17,31,32,39,40]$. In complex matrices, the rate of reduction was lower, around $3 \log _{10}[14,19,20]$ or was not satisfactory [20] due to the presence of PCR inhibitors and of solids, which react with the PMA. In our study, when the optimal conditions provided by the desirability function were applied in nine piggery effluent samples, the $\Delta_{\text {viable }}$ and $\Delta_{\text {dead }}$ values were generally close to their target values.

As the quantification of dead cells depends on the activation of the acid nucleic-bound dye, quantification could be improved by replacing the halogen lamp used in this study by $460 \mathrm{~nm}$ LEDs, which have the advantage of emitting light at a wavelength close to the maximum absorption of PMA $(456 \mathrm{~nm})$ and do not generate heat [27]. Moreover, it should be noted that the length of the target gene may also affect the effectiveness of the dye. Longer amplicons appear to be more appropriate than shorter ones to reflect the extent of cell death induced by the PMA or EMA-pretreatment [31, 40-47]. However, amplification of long fragments (longer than $400 \mathrm{bp}$ ) increases the likelihood of the formation of secondary structures, thereby reducing PCR efficiency. In our study, the small size of the target fragment (113 bp), does not appear to have negatively influenced the quantification of the dead cells, as most of the nine signals were very close to threshold of the qPCR.

The efficiency of the PMA pretreatment also depends on the target microorganism, which may complicate the selection of the optimal combination of factors $[43,45]$. Furthermore, factors such as the ratio of dead cells to viable cells may influence the efficiency of the PMA pretreatment [11, 14, 31]. It should be noted that the piggery effluents tested in our study probably contained a substantial number of cells with damaged membranes that may incorporate PMA and hence interfere with the quantification of the target amplicon after PMA treatment.

In our study, the efficiency of the PMA pretreatment was not impacted by the range of $\mathrm{pH}$ (7.3 to 8.5), but depended on the type of effluents, which mainly differed in their TSS contents and turbidity (Table 3 ). Bae and Wuertz [19] and Taskin et al. [22] reported that TSS contents $>1 \mathrm{~g} \mathrm{~L}^{-1}$ and $4 \mathrm{~g} \mathrm{~L}^{-1}$, respectively, interfered with the cross-linking of PMA, leading to underestimation of heat-treated cells. Wagner et al. [20] reported that the black color of digested sludge limited light penetration thus preventing the crosslinking step of the dye. Similarly, Li et al. [21] pointed out that sludge 
inhibits the efficiency of PMA due to the presence of dark particles or inhibitory substances. Data on PMA reported by Luo et al. [18] suggest that turbidity has an effect on PMA treatment when the turbidity of samples is more than $10 \mathrm{NTU}$. However, our data showed that even when turbidity ranged from 100 to 4600 NTU, PMA adequately distinguished between viable and dead cells of L. monocytogenes.

In our study, as the optimal combination of the three factors was estimated taking into account the difference in composition of the two matrices, the variations in the TSS levels in the samples of manure (ranging from 6 to $23 \mathrm{~g} \mathrm{~L}^{-1}$ ) and in samples of lagoon effluent (1.3 to $1.8 \mathrm{~g} \mathrm{~L}^{-1}$ ) had no significant impact on the $\Delta_{\text {viable }}$ values. Nevertheless, the two manures with the highest level of TSS led to the greater underestimation of the number of dead cells.

\section{Conclusion}

In our experimental conditions (small target amplicon, high level of TSS and high turbidity, use of a halogen lamp to activate the dye), the use of the two combinations of factors selected according the type of matrix based on the desirability function, allowed us to accurately estimate the number of viable and dead cells of $L$. monocytogenes in both manure and lagoon effluent. Our results confirm that PMA-qPCR can be used on undiluted turbid effluent provided that preliminary tests are performed to estimate the optimal conditions for a given matrix.

\section{Methods}

\section{Bacterial strain and culture conditions}

A strain of L. monocytogenes, originally isolated from pig manure, was used throughout this study. Stock culture was stored at $-80{ }^{\circ} \mathrm{C}$. Cells were cultivated for $24 \mathrm{~h}$ at $37{ }^{\circ} \mathrm{C}$ in nutritive broth (OXOID) supplemented with $0.3 \%$ glucose (NBG medium) to obtain stationary-phase cultures. Prior to exposure assays, exponential-phase cultures were prepared by inoculating $100 \mathrm{~mL}$ of NBG with $150 \mu \mathrm{L}$ of a stationary-phase culture NBG and incubating the resulting culture at $37{ }^{\circ} \mathrm{C}$ for $17 \mathrm{~h}$. To ensure that the exponential phase was reached, viable cells were quantified both by culture and qPCR targeting hlyA gene of L. monocytogenes.

\section{Samples of livestock effluent}

The experimental design was applied on two types of livestock effluent: raw manure (henceforth referred to as 'manure' samples) and lagoon effluent collected from a piggery located in Brittany (France). Raw manure was stored in a tank. After centrifugation, the liquid phase was treated by aerobic digestion. The biologically treated manure was then stored in a settling tank. The liquid supernatant was sent to a lagoon. Manure and lagoon samples (10 l) were collected and transferred to a one liter flask. The flasks were then transferred to the laboratory and stored at $4{ }^{\circ} \mathrm{C}$ until physical-chemical characterization and inoculation. The $\mathrm{pH}$ of the manure was 7.7 and the lagoon $\mathrm{pH}$ was 8.9. Total suspended solids (TSS) in the manure were 20.5 g. $\mathrm{kg}^{-1}$ and $0.4 \mathrm{~g} . \mathrm{kg}^{-1}$ in the lagoon.

Before inoculation, $150 \mathrm{~mL}$ of manure and lagoon were placed in a flask and stirred with a magnetic stirrer for $15 \mathrm{~min}$.

\section{Preparation of viable and dead cells}

To maximize the density of viable cells (i.e. $100 \%$ of viable cells), exponential phase cultures of $L$. monocytogenes grown in NBG were used to inoculate the manure and the lagoon effluent. To generate a population of dead cells (cells with compromised membrane integrity), $5 \mathrm{~mL}$ of the exponential phase cultures were transferred in a $12 \mathrm{~mL}$ tube immersed in hot water bath at $90{ }^{\circ} \mathrm{C}$ for $15 \mathrm{~min}$. The cell suspensions were cooled to ambient temperature before use. The viability of the cells was estimated by plating the $L$. monocytogenes suspensions on TSYE (OXOID) agar, and incubating them at $37{ }^{\circ} \mathrm{C}$ for $24 \mathrm{~h}$. Results are expressed as colony forming units (cfu) per $\mathrm{mL}$. The absence of viable cells of $L$. monocytogenes was confirmed by spreading $0.1 \mathrm{~mL}$ aliquots of heat-killed cells on TSYE agar (OXOID) which was then incubated for $48 \mathrm{~h}$ at $37{ }^{\circ} \mathrm{C}$. Aliquots of heat-killed and viable cells containing $10^{7}-10^{8}$ cells per $\mathrm{mL}$ were inoculated $(1 / 10 \mathrm{v} / \mathrm{v})$ in the manure and in lagoon samples described above.

\section{DNA extraction and quantification}

To study the effect of PMA, DNA from viable and heatkilled L. monocytogenes inoculated in manure and in lagoon samples, was extracted using a Nucleospin kit for soil (Macherey Nagel) according to the manufacturer's instructions except that a FastPrep-24 instrument was used to lyse cells (MP Biomedicals) and a minor modification was made in the elution step. The eluent was split into four successive elutions (each performed with $25 \mu \mathrm{L}$ of elution buffer). The Nucleospin kit was chosen for its ability to extract high quality DNA in large quantities from manures [48]. The primers and the probe targeting the hlyA gene (listed in Table 4), along with the quantification procedure for L. monocytogenes are described in Nogva et al. [49]. PCR was performed using the epMotion 5070 pipetting system (Eppendorf). Amplification reactions $(25 \mu \mathrm{L})$ contained $200 \mu \mathrm{M}$ of dNTP; $0.1 \mu \mathrm{M}$ specific probe of $L$. monocytogenes; $0.3 \mu \mathrm{M}$ of each specific primer of $L$. monocytogenes, $12.5 \mu \mathrm{l}$ of IQ Supermix (Biorad) and $2 \mu \mathrm{l}$ of $1 / 10$ diluted DNA. The cycling parameters were as follows: $95^{\circ}$ $\mathrm{C}$ for $10 \mathrm{~min}$, followed by 40 cycles at $95^{\circ} \mathrm{C}$ for $20 \mathrm{~s}$ and at $60{ }^{\circ} \mathrm{C}$ for $60 \mathrm{~s}$. PCR amplification of $113 \mathrm{bp}$ was carried out in a CFX96 real-time PCR machine (Bio-Rad Laboratories). Real time PCR results were analyzed using the CFX 
Table 4 Primers and probe used for L. monocytogenes quantification

\begin{tabular}{lll}
\hline $\begin{array}{l}\text { Probe or } \\
\text { primer }\end{array}$ & Sequence $\left(5^{\prime}-3^{\prime}\right)$ & $\begin{array}{l}\text { Denaturation } \\
\text { temperature }\left({ }^{\circ} \mathrm{C}\right)\end{array}$ \\
\hline Primers & & \\
Forward & TGC AAG TCC TAA GAC GCC A & 60.3 \\
Reverse & CAC TGC ATC TCC GTG GTA TAC TAA & 60.3 \\
Probe & CGA TT CAT CCG CGT GTT TCT TTT CG & 70.2 \\
\hline
\end{tabular}

manager software Version 1.1 (Bio-Rad Laboratories). The PCR standard curve was prepared by 10 -fold dilution of bacterial genomic DNA extracted from the pure culture of L. monocytogenes with the Wizard genomic DNA purification Kit (Promega) according to the manufacturer's instructions. As $h l y A$ is present as a single copy in the genome of L. monocytogenes [50], the results are expressed as cfu equivalent (cfu-eq). Dilutions ranged from $4.5 \times 10^{8}$ to $4.5 \times 10^{0} \mathrm{cfu}$-eq. Standard curves were generated by plotting threshold cycles $(\mathrm{Ct})$ against cfu-eq. The quantification limit was $4.2 \log _{10}$ cfu-eq $\mathrm{mL}^{-1}$ for the manure and $3.9 \log _{10}$ cfu-eq $\mathrm{mL}^{-1}$ for the lagoon effluent.

\section{Propidium mono azide treatment}

Propidium mono azide (PMA) stock solution $(20 \mathrm{mM}$, Biotium) was stored at $-20{ }^{\circ} \mathrm{C}$ in the dark. The stock solution was transferred into highly light transparent $12 \mathrm{~mL}$ polypropylene tubes (Greiner Bio-one) containing either $400 \mu \mathrm{L}$ of manure or $600 \mu \mathrm{L}$ of lagoon samples spiked with suspensions of viable or heat-killed cells. After incubation in the dark, the tubes were placed horizontally on ice at a distance of about $20 \mathrm{~cm}$ from a 650 W halogen lamp (Inspecktor, ref 100512, R75 $118 \mathrm{~mm}$ ) as recommended by the manufacturer. After photo-induced crosslinking, $250 \mu \mathrm{L}$ and $500 \mu \mathrm{L}$ of PMA-treated manure and lagoon samples, respectively, were transferred to a $2 \mathrm{~mL}$ Eppendorf tube and centrifuged for $5 \mathrm{~min}$ at $5000 \mathrm{~g}$. The supernatant was removed and the pellet was immediately placed at $-20{ }^{\circ} \mathrm{C}$. The concentrations of the PMA, the incubation time in the dark and under light are mentioned below.

\section{Experimental shell designs}

Statistical analyses were performed using Statgraphics Centurion XVI software (StatPoint Technologies, Inc.). Experiments were conducted following a Doehlert experimental uniform shell design, displaying a uniform distribution of the points on a spherical shell and allowing a number of distinct levels for each factor [51]. Three factors were studied. The minimum and maximum values of each factor were selected according to values reported in the literature. The concentration of PMA in the two matrices was studied at five levels (20, 90, 160, 230, $300 \mu \mathrm{M})$, three different incubation times
(5, 15, $30 \mathrm{~min})$ and seven photoactivation times (2, 11, $20,29,38,47,56 \mathrm{~min}$ ) were studied. The number of experiments required $(\mathrm{N})$ is given by $\mathrm{N}=\mathrm{k}^{2}+\mathrm{k}+1+\mathrm{n}$, where $k$ is the number of factors $(k=3)$ and $n$ is the number of replications at the center of the experimental domain $(n=3)$. Replicates at the central level of the factors were performed to validate the model by means of an estimate of experimental variance. Sixteen experiments were carried out per matrix (manure and lagoon) and per physiological state (viable or heat-killed) leading to a total of four experimental designs.

To optimize PMA pretreatment, it is important to note that under certain conditions, PMA (i) may enter viable cells (leading to underestimation of viable bacteria) and (ii) may react with the organic matrix and consequently not penetrate all the dead cells (leading to underestimation of the dead bacteria). Thus, the optimal conditions determined by the experimental design must maximize penetration of dead cells by PMA and minimize entry into viable cells.

The efficiency of the PMA pretreatment on the quantification of viable and dead cells was estimated by two calculated values: $\Delta_{\text {viable }}$ Eq. (1) and $\Delta_{\text {dead, }}$ Eq. (2).

$$
\begin{aligned}
& \Delta_{\text {viable }}=\log _{10} \mathrm{C}-\log _{10} \mathrm{X} \\
& \Delta_{\text {dead }}=\log _{10} \mathrm{C}_{\text {heat }}-\log _{10} \mathrm{X}
\end{aligned}
$$

where $C$ is the concentration of the inoculated cultivable cells, expressed in cfu. $\mathrm{mL}^{-1}, \mathrm{C}_{\text {heat }}$, the concentration of the inoculated cultivable cells before heat treatment, expressed in cfu. $\mathrm{mL}^{-1}$ and $\mathrm{X}$, the concentration of cells estimated by qPCR after PMA pretreatment (expressed in cfu-eq. $\mathrm{mL}^{-1}$ ).

As the first term of both equations was a constant, we assumed that (i) the higher the $\Delta_{\text {viable }}$ value, the greater the underestimation of the number of viable cells by the PMA-qPCR and (ii), the lower the $\Delta_{\text {dead }}$ value, the greater the underestimation of the number of dead cells by the PMA-qPCR.

In the experiments carried out on L. monocytogenes inoculated as exponential phase cells, we considered that the difference between the number of cultivable cells per $\mathrm{mL}$ and the number of cells per $\mathrm{mL}$ measured by qPCR after PMA treatment $\left(\Delta_{\text {viable }}\right)$ had to tend to zero, whereas in the experiments performed with dead cells, the difference between the number of cultivable cells (before heat treatment) and the number of cells measured by qPCR after PMA treatment $\left(\Delta_{\text {dead }}\right)$ had to be as high as possible. According to the concentration of viable cells inoculated in the matrices $\left(8.3 \log _{10} \mathrm{cfu} \mathrm{mL} \mathrm{m}^{-1}\right.$ in manure and $7.3 \log _{10} \mathrm{cfu} \mathrm{mL}^{-1}$ in lagoon samples) and the limit of quantification of the qPCR for each matrix, $\Delta_{\text {dead }}$ had to tend to $4.1 \log _{10}$ cfu-eq. $\mathrm{mL}^{-1}$ in manure and to $3.4 \log _{10}$ cfu-eq. $\mathrm{mL}^{-1}$ in lagoon samples. 
To identify the factor settings that optimize the two responses simultaneously (i.e. minimize $\Delta_{\text {viable }}$ and maximize $\Delta_{\text {dead }}$ ) the data was analyzed by combining the individual responses into a desirability function, as proposed by Derringer and Suich [52]. The responses were transformed into a dimensionless desirability scale $\left(\mathrm{d}_{\mathrm{i}}\right)$ defined as a partial desirability function ranging from 0 (for a completely undesirable response) to 1 (when the response reached the target value). Once the function was defined for each response, an overall objective function (D), representing the global desirability function, was calculated by determining the geometric mean of the individual desirability. $\mathrm{D}$ can be calculated by the expression $\mathrm{D}=\left(\mathrm{d}_{1}^{\mathrm{p} 1} \cdot \mathrm{d}_{2}{ }^{\mathrm{p} 2} \cdot \ldots \mathrm{d}_{\mathrm{m}}{ }^{\mathrm{pm}}\right)^{1 / \mathrm{m}}$ where $m$ is the number of responses and pm their associated weight. The weight of the response represents the relative importance of each individual function $\mathrm{d}_{\mathrm{i}}$ and may range between 0.1 and 10 . With a weight of $1, d_{i}$ varies in a linear way. In our study, weights equal to 1 were selected. The criteria for optimization of individual responses are listed in Table 5.

Application of the PMA pretreatment on piggery effluents The optimal conditions determined by the experimental design were tested on nine livestock effluents collected from piggeries located in Britany: five raw manures and four lagoon effluents. Turbidity, $\mathrm{pH}$, volatile solids (VS) and total suspended solids (TSS) were performed on the nine effluents. Each sample was inoculated in triplicate with exponential phase cells of heat-killed or living L. monocytogenes cells at a concentration of $2.5 \times 10^{7} \mathrm{cfu} \mathrm{mL}^{-1}$ in the manures and of $3 \times 10^{7} \mathrm{cfu} \mathrm{\textrm {mL } ^ { - 1 }}$ in the lagoon effluents. To compare the $\Delta_{\text {viable }}$ and $\Delta_{\text {dead }}$ values among the effluents tested, the PMA pretreatment with the optimized conditions was applied, as described above.

Correlations of the physical-chemical parameters with the efficiency of PMA were analyzed using a repeatedmeasures one-way ANOVA followed by a StudentNewman-Keuls test in an all pairwise fashion. Bacterial concentrations were logarithmically transformed prior

Table 5 Criteria for multivariate optimization of individual responses

\begin{tabular}{lllllll}
\hline Matrix & Response & Target & $\begin{array}{l}\text { Lower } \\
\text { limit }\end{array}$ & $\begin{array}{l}\text { Upper } \\
\text { limit }\end{array}$ & Weight & Importance \\
\hline Manure & $\Delta_{\text {viable }}^{\mathrm{a}}$ & Target $=0$ & 0.2 & 1.6 & 1 & 3 \\
& $\Delta_{\text {dead }}^{\mathrm{b}}$ & Target $=4.1$ & 2.4 & 4.1 & 1 & 3 \\
& & & & & & 3 \\
Lagoon & $\Delta_{\text {viable }}$ & Target $=0$ & 0.1 & 1.2 & 1 & 3 \\
& $\Delta_{\text {dead }}$ & Target $=3.4$ & 1.2 & 3.4 & 1 & 3 \\
\hline
\end{tabular}

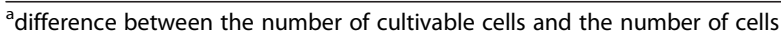
measured by QPCR after PMA treatment

${ }^{b}$ difference between the number of cultivable cells (before heat treatment) and the number of cells measured by GPCR after PMA treatment to analysis. Spearman rank correlation was performed to test associations between $\Delta_{\text {viable }}$ and physical-chemical parameters of the effluent samples. All statistical tests were performed with XLSTAT 2010.4.

\section{Abbreviations}

EMA: Ethidium monoazide; PMA: Propidium monoazide; qPCR: Quantitative polymerase chain reaction; RT-PCR: Reverse transcription polymerase chain reaction; CIP: Collection de I'Institut Pasteur; VBNC: Viable but nonculturable.

\section{Competing interests}

The authors declare that they have no competing interests.

\section{Authors' contributions}

JD and AMP designed laboratory work. JD performed all laboratory work, as well as drafting the manuscript. AMP finalized the manuscript. MC performed the experimental design, interpreted the statistical data and co-wrote the manuscript. All authors read and approved the final manuscript.

\section{Acknowledgements}

This research was funded by the French Agency for Food, Environmental and Occupational Health and Safety (ANSES) and by the French Environment and Energy Management Agency (ADEME). J. Desneux is recipient of an Irstea-Région Bretagne fellowship.

\section{Author details}

${ }^{1}$ IRSTEA, 17 avenue de Cucillé, 35044 Rennes, France. ²Université Européenne de Bretagne, Rennes, France. ${ }^{3}$ French Agency for Food Environmental and Occupational Health Safety, Anses, Laboratory of Ploufragan-Plouzané, F-22440 Ploufragan, France.

Received: 2 December 2014 Accepted: 7 August 2015

Published online: 16 August 2015

\section{References}

1. Garcia R, Baelum J, Fredslund L, Santorum P, Jacobsen CS. Influence of temperature and predation on survival of salmonella enterica serovar typhimurium and expression of invA in soil and manure-amended soil. Appl Environ Microbiol. 2010;76(15):5025-31.

2. Jacobsen CS, Holben WE. Quantification of mRNA in Salmonella sp seeded soil and chicken manure using magnetic capture hybridization RT-PCR. J Microbiol Methods. 2007;69(2):315-21.

3. Jiang XP, Islam M, Morgan J, Doyle MP. Fate of Listeria monocytogenes in bovine manure-amended soil. J Food Prot. 2004;67(8):1676-81.

4. Gedalanga PB, Olson BH. Development of a quantitative PCR method to differentiate between viable and nonviable bacteria in environmental water samples. Appl Microbiol Biotechnol. 2009;82(3):587-96.

5. Garrec N, Picard-Bonnaud F, Pourcher AM. Occurrence of Listeria sp and L-monocytogenes in sewage sludge used for land application: effect of dewatering, liming and storage tank on survival of Listeria species. Fems Immunol Med Microbiol. 2003;35(3):275-83.

6. Fujimoto J, Watanabe K. Quantitative detection of viable Bifidobacterium bifidum BF-1 cells in human feces by using propidium monoazide and strain-specific primers. Appl Environ Microbiol. 2013;79(7):2182-8.

7. Dong S, Hong P-Y, Nguyen T. Persistence of Bacteroides ovatus under simulated sunlight irradiation. BMC Microbiol. 2014;14(1):178.

8. Nocker A, Cheung C-Y, Camper AK. Comparison of propidium monoazide with ethidium monoazide for differentiation of live vs. dead bacteria by selective removal of DNA from dead cells. J Microbiol Methods. 2006;67(2):310-20.

9. Nocker A, Sossa KE, Camper AK. Molecular monitoring of disinfection efficacy using propidium monoazide in combination with quantitative PCR. J Microbiol Methods. 2007;70(2):252-60.

10. Cawthorn DM, Witthuhn RC. Selective PCR detection of viable Enterobacter sakazakii cells utilizing propidium monoazide or ethidium bromide monoazide. J Appl Microbiol. 2008;105(4):1178-85.

11. Pan Y, Breidt Jr F. Enumeration of viable Listeria monocytogenes cells by real-time PCR with propidium monoazide and ethidium monoazide in the presence of dead cells. Appl Environ Microbiol. 2007;73(24):8028-31. 
12. Fittipaldi M, Nocker A, Codony F. Progress in understanding preferential detection of live cells using viability dyes in combination with DNA amplification. J Microbiol Methods. 2012;91(2):276-89.

13. Nkuipou-Kenfack E, Engel H, Fakih S, Nocker A. Improving efficiency of viability-PCR for selective detection of live cells. J Microbiol Methods. 2013;93(1):20-4.

14. Varma M, Field R, Stinson M, Rukovets B, Wymer L, Hauglanda R. Quantitative real-time PCR analysis of total and propidium monoazide-resistant fecal indicator bacteria in wastewater. Water Res. 2009;43(19):4790-801.

15. Pisz JM, Lawrence JR, Schafer AN, Siciliano SD. Differentiation of genes extracted from non-viable versus viable micro-organisms in environmental samples using ethidium monoazide bromide. J Microbiol Methods. 2007:71(3):312-8.

16. Adela Yanez M, Nocker A, Soria-Soria E, Murtula R, Martinez L, Catalan V. Quantification of viable Legionella pneumophila cells using propidium monoazide combined with quantitative PCR. J Microbiol Methods. 2011;85(2):124-30.

17. Nocker A, Camper AK. Selective removal of DNA from dead cells of mixed bacterial communities by use of ethidium monoazide. Appl Environ Microbiol. 2006;72(3):1997-2004.

18. Luo J-F, Lin W-T, Guo Y. Method to detect only viable cells in microbial ecology. Appl Microbiol Biotechnol. 2010;86(1):377-84.

19. Bae $S$, Wuertz S. Discrimination of viable and dead fecal bacteroidales bacteria by quantitative PCR with propidium monoazide. Appl Environ Microbiol. 2009;75(9):2940-4.

20. Wagner AO, Malin C, Knapp BA, IIImer P. Removal of free extracellular DNA from environmental samples by ethidium monoazide and propidium monoazide. Appl Environ Microbiol. 2008;74(8):2537-9.

21. Li D, Tong T, Zeng S, Lin Y, Wu S, He M. Quantification of viable bacteria in wastewater treatment plants by using propidium monoazide combined with quantitative PCR (PMA-qPCR). J Environ Sci-China. 2014;26(2):299-306.

22. Taskin B, Gozen AG, Duran M. Selective quantification of viable escherichia coli bacteria in biosolids by quantitative PCR with propidium monoazide modification. Appl Environ Microbiol. 2011;77(13):4329-35.

23. Besnard V, Federighi M, Declerq E, Jugiau F, Cappelier JM. Environmental and physico-chemical factors induce VBNC state in Listeria monocytogenes. Vet Res. 2002;33(4):359-70.

24. Lindback T, Rottenberg ME, Roche SM, Rorvik LM. The ability to enter into an avirulent Viable But Non-Culturable (VBNC) form is widespread among Listeria monocytogenes isolates from salmon, patients and environment. Vet Res. 2010;41(1):8

25. Pourcher AM, Jadas-Hecart A, Cotinet P, Dabert P, Ziebal C, Le Roux S, et al. Effect of land application of manure from enrofloxacin-treated chickens on ciprofloxacin resistance of Enterobacteriaceae in soil. Sci Total Environ. 2014;482:269-75

26. Oliver JD. Recent findings on the viable but nonculturable state in pathogenic bacteria. Fems Microbiol Rev. 2010;34(4):415-25

27. Vesper S, McKinstry C, Hartmann C, Neace M, Yoder S, Vesper A. Quantifying fungal viability in air and water samples using quantitative PCR after treatment with propidium monoazide (PMA). J Microbiol Methods. 2008;72(2):180-4.

28. Agusti G, Codony F, Fittipaldi M, Adrados B, Morato J. Viability determination of helicobacter pylori using propidium monoazide quantitative PCR. Helicobacter. 2010;15(5):473-6.

29. Andorra I, Esteve-Zarzoso B, Guillamon JM, Mas A. Determination of viable wine yeast using DNA binding dyes and quantitative PCR. Int J Food Microbiol. 2010;144(2):257-62.

30. Delgado-Viscogliosi P, Solignac L, Delattre J-M. Viability PCR, a culture-independent method for rapid and selective quantification of viable Legionella pneumophila cells in environmental water samples. Appl Environ Microbiol. 2009;75(11):3502-12.

31. Lovdal T, Hovda MB, Bjorkblom B, Moller SG. Propidium monoazide combined with real-time quantitative PCR underestimates heat-killed Listeria innocua. J Microbiol Methods. 2011;85(2):164-9.

32. Nocker A, Mazza A, Masson L, Camper AK, Brousseau R. Selective detection of live bacteria combining propidium monoazide sample treatment with microarray technology. J Microbiol Methods. 2009;76(3):253-61.

33. Rawsthorne $H$, Dock CN, Jaykus LA. PCR-based method using propidium monoazide to distinguish viable from nonviable bacillus subtilis spores. Appl Environ Microbiol. 2009;75(9):2936-9.
34. Fittipaldi M, Pino Rodriguez NJ, Adrados B, Agusti G, Penuela G, Morato J, et al. Discrimination of viable acanthamoeba castellani trophozoites and cysts by propidium monoazide real-time polymerase chain reaction. J Eukaryot Microbiol. 2011;58(4):359-64.

35. Kramer M, Obermajer N, Matijasic BB, Rogelj I, Kmetec V. Quantification of live and dead probiotic bacteria in lyophilised product by real-time PCR and by flow cytometry. Appl Microbiol Biotechnol. 2009;84(6):1137-47.

36. Tian W, Zhang Z, Liu D, Zhou T, Shen Q, Shen B. An optimized DNA extraction and purification method from dairy manure compost for genetic diversity analysis. World J Microbiol Biotechnol. 2013;29(5):815-23.

37. Shi H, Xu W, Luo Y, Chen L, Liang Z, Zhou X, et al. The effect of various environmental factors on the ethidium monazite and quantitative PCR method to detect viable bacteria. J Appl Microbiol. 2011;111(5):1194-204.

38. Fittipaldi M, Codony F, Adrados B, Camper AK, Morato J. Viable real-time PCR in environmental samples: can all data be interpreted directly. Microbial Ecology. 2011;61(1):7-12.

39. Chang B, Sugiyama K, Taguri T, Amemura-Maekawa J, Kura F, Watanabe H. Specific detection of viable Legionella cells by combined Use of photoactivated ethidium monoazide and PCR/real-time PCR. Appl Environ Microbiol. 2009;75(1):147-53.

40. Rudi K, Naterstad K, Dromtorp SM, Holo H. Detection of viable and dead Listeria monocytogenes on gouda-like cheeses by real-time PCR. Lett Appl Microbiol. 2005;40(4):301-6.

41. Rudi K, Moen B, Dromtorp SM, Holck AL. Use of ethidium monoazide and $P C R$ in combination for quantification of viable and dead cells in complex samples. Appl Environ Microbiol. 2005;71(2):1018-24.

42. Banihashemi A, Van Dyke MI, Huck PM. Long-amplicon propidium monoazide-PCR enumeration assay to detect viable Campylobacter and Salmonella. J Appl Microbiol. 2012;113(4):863-73.

43. Contreras PJ, Urrutia H, Sossa K, Nocker A. Effect of PCR amplicon length on suppressing signals from membrane-compromised cells by propidium monoazide treatment. J Microbiol Methods. 2011;87(1):89-95.

44. Soejima T, lida K-i, Qin T, Taniai H, Seki M, Yoshida S-i. Method to detect only live bacteria during PCR amplification. J Clin Microbiol. 2008;46(7):2305-13.

45. Soejima T, Schlitt-Dittrich F, Yoshida S-i. Polymerase chain reaction amplification length-dependent ethidium monoazide suppression power for heat-killed cells of Enterobacteriaceae. Anal Biochem. 2011;418(1):37-43.

46. Martin B, Raurich S, Garriga M, Aymerich T. Effect of amplicon length in propidium monoazide quantitative PCR for the enumeration of viable cells of salmonella in cooked Ham. Food Anal Methods. 2013;6(2):683-90.

47. Chang B, Taguri T, Sugiyama K, Amemura-Maekawa J, Kura F, Watanabe H. Comparison of ethidium monoazide and propidium monoazide for the selective detection of viable Legionella cells. Jpn J Infect Dis. 2010;63(2):119-23.

48. Desneux J, Pourcher A-M. Comparison of DNA extraction kits and modification of DNA elution procedure for the quantitation of subdominant bacteria from piggery effluents with real-time PCR. Microbiologyopen. 2014;3(4):437-45.

49. Nogva HK, Rudi K, Naterstad K, Holck A, Lillehaug D. Application of 5'-nuclease PCR for quantitative detection of Listeria monocytogenes in pure cultures, water, skim milk, and unpasteurized whole milk. Appl Environ Microbiol. 2000;66(10):4266-71.

50. Mengaud J, Vicente MF, Chenevert J, Pereira JM, Geoffroy C, Gicquelsanzey $B$, et al. Expression in escherichia-coli and sequence-analysis of the listeriolysin-o determinant of listeria-monocytogenes. Infect Immun. 1988:56(4):766-72.

51. Doehlert DH. Uniform shell designs. J Royal Stat Soc Series C (Applied Statistics). 1970;19(3):231-9.

52. Derringer $G$, Suich R. Simultaneous optimization of several response variables. J Qual Technol. 1980;12(4):214-9. 